\title{
Coffee Consumption Could Affect the Activity of Some Liver Enzymes and Other Biochemical Parameters in Healthy Drinkers
}

\author{
Anaelechi J. Onuegbu a Japhet M. Olisekodiaka ${ }^{a}$ Olubukunmi E. Adebolu ${ }^{a}$ \\ Adekunle Adesiyan $^{\text {a }}$ Olugbenga E. Ayodele ${ }^{b}$ \\ Departments of ${ }^{\mathrm{a} B i o m e d i c a l ~ S c i e n c e s ~ a n d ~}{ }^{\mathrm{b}}$ Medicine, College of Health Sciences, Ladoke Akintola University of \\ Technology, Ogbomoso, Nigeria
}

\section{Key Words}

Coffee $\cdot$ Alanine aminotransferase $\cdot$ Aspartate

aminotransferase $\cdot$ Alkaline phosphatase $\cdot$ Bilirubin result obtained from the study suggests that short-term consumption of coffee might have a significant effect on the integrity of the liver function tests studied.

Copyright $\odot 2011$ S. Karger AG, Basel

\begin{abstract}
Objective: To investigate the effect of coffee consumption on some liver function indices in adult male and female $\mathrm{Ni}$ gerians. Subjects and Methods: Thirty apparently healthy subjects, consisting of 18 men and 12 women, were made to consume $2 \mathrm{~g}$ of coffee daily for a total of 30 days. Activities of aspartate transaminase (AST), alanine transaminase (ALT), alkaline phosphatase (ALP) and plasma concentrations of total and conjugated bilirubin, total protein and albumin were determined using standard methods. Results: Relative to baseline values, coffee consumption raised mean levels of ALT by 4 IU/I $(p<0.001)$, AST by $2.01 \mathrm{U} / \mathrm{I}(\mathrm{p}<0.001)$, ALP by $3.01 \mathrm{U} / \mathrm{l}(\mathrm{p}<0.01)$, total bilirubin by $0.90 \mathrm{mg} / \mathrm{dl}(\mathrm{p}<0.05)$ and total protein by $1.1 \mathrm{~g} / \mathrm{l}(\mathrm{p}<0.05)$. Gender differences were observed. Significantly higher mean ALP concentration was only seen in male subjects, while mean bilirubin concentration was significantly raised in female volunteers alone. On the other hand, the mean total protein and albumin concentrations in individual male and female groups were not significantly altered ( $p>0.05$ in each case). Conclusion: The
\end{abstract}

\section{Introduction}

Coffee is a widely consumed stimulant beverage prepared from roasted seeds, commonly called coffee beans, of the coffee plant [1]. It was first consumed in the 9th century, in the highlands of Ethiopia where it was discovered. Coffee spread to Italy, then to the rest of Europe and the Americas. Today, coffee is one of the most popular beverages worldwide [2,3].

Scientific studies have examined the relationship between coffee consumption and an array of medical conditions. Findings are contradictory as to whether coffee has any specific health benefits, and results are similarly conflicting regarding negative effects of coffee consumption [4]. It has been suggested that coffee consumption may help prevent several chronic diseases, including type 2 diabetes mellitus, Parkinson's disease, liver cirrhosis and hepatocellular carcinoma [5], but it increases the risk of acid reflux and associated diseases.

\section{KARGER}

Fax +41 613061234

E-Mail karger@karger.ch

www.karger.com
(C) 2011 S. Karger AG, Basel

1011-7571/11/0206-0514\$38.00/0

Accessible online at:

www.karger.com/mpp
Anaelechi J. Onuegbu

Department of Biomedical Sciences College of Health Sciences PMB 4400, Osogbo Ladoke Akintola University of Technology Ogbomoso (Nigeria)

Tel. +234 803717 5648, E-Mail ajonuegbu@yahoo.com 
Some health effects of coffee are due to its caffeine content, as the benefits are only observed in those who drink caffeinated coffee, while others appear to be due to other components as exemplified by the presence of the antioxidants that prevent free radicals from causing cell damage [6]. Coffee's negative health effects are also mostly due to its caffeine content. Excess coffee consumption may lead to a magnesium deficiency or hypomagnesemia [7] and may be a risk factor for coronary heart disease. The liver plays a major role in metabolism, synthesis and storage of essential substances in the body, as well as the detoxification of xenobiotics [8]. The world's primary source of caffeine is the coffee bean, from which coffee is brewed. Caffeine, an active ingredient of coffee, is a central nervous system and metabolic stimulant [9] and is used both recreationally and medically to reduce physical fatigue and restore mental alertness when unusual drowsiness or weakness occurs. After absorption, caffeine is metabolized in the liver into three primary metabolites: paraxanthine: $84 \%$; theobromine: $12 \%$, and theophylline: $4 \%[10]$.

Factors such as age, liver function, pregnancy, some concurrent medications, and the level of enzymes in the liver needed for caffeine metabolism could affect caffeine metabolism, making its half-life to vary widely among individuals. In healthy adults, caffeine's half-life is approximately 3-4 h [11]. In severe liver disease when its half-life can increase to $96 \mathrm{~h}$ [12], caffeine can accumulate in an individual. Caffeine is metabolized in the liver by the cytochrome P450 oxidase enzyme system into three metabolic dimethylxanthines, paraxanthine, theobromine, and theophylline - with each having its own effects on the body.

In recent years a number of studies have suggested potential health risks associated with coffee consumption; however, the results are conflicting $[13,14]$. A number of investigators have focused their attention on the relationship between the consumption of coffee and liver disease. For instance, Cadden et al. [14] have reported the beneficial effects of coffee on abnormal liver biochemistry, cirrhosis and hepatocellular carcinoma. Another study carried out by Casiglia et al. [15] reported that subjects who consumed three or more cups of coffee per day had significantly lower plasma levels of liver enzymes and bilirubin than those who consumed 0-2 cups/day. The researchers hypothesized that liver enzymes are a target for caffeine or other components of coffee. Among persons at high risk for liver injury, coffee drinking and caffeine consumption from beverages have been associated with lower risk of injury [16]. In contrast, Urgert et al. [17] reported an increase in the concentration of liver enzymes following the consumption of coffee diterpenes. Boekschoten et al. [18] also observed an increase in plasma activities of liver enzymes and a tendency of alkaline phosphatase (ALP) to be decreased; however, the mechanism through which coffee affects the liver is still unknown.

Nigerians seem to consume more coffee these days even though the quantity consumed might be less than that in many European countries [19]. Considering the likely effects of coffee consumption on health status, it might be suggested that coffee consumption may affect liver function. However, detailed studies on the effect of coffee intake in this community are lacking. This study was therefore designed to determine the short-term effect of coffee consumption on plasma activity of liver enzymes, total and conjugated bilirubin, and total protein and albumin levels in male and female adult Nigerians.

\section{Subjects and Methods}

\section{Subjects}

The study lasted from June to August, 2008. Thirty healthy volunteers were recruited for the study, through personal contact after proper consultation. The volunteers included both men and women most of whom were students of Ladoke Akintola University of Technology, Osogbo Campus. Ethical approval was obtained from the Ladoke Akintola University of Technology Ethics Committee. The study protocol and expected changes in liver enzymes and other parameters of the liver function test were carefully explained to them. Subjects consisted of 18 men and 12 women with a mean age $23.6 \pm 2.0$ years (range 20-28) and mean body mass index of $22.1 \pm 2.31 \mathrm{~kg} / \mathrm{m}^{2}$. Pregnant women and those taking oral contraceptives were excluded from the study. None of the subjects reported a history of gastrointestinal, kidney or liver disease. All subjects were apparently healthy, non-alcohol consumers and none was taking medication known to affect liver function. Informed consent was obtained from each subject before commencement of the study. Only one brand of commercial coffee was used for the study in which each subject consumed a moderate quantity of $2 \mathrm{~g}$ of coffee daily over a period of 30 days. Subjects were allowed to use little milk and/or sugar to enhance compliance. Subjects were also asked to maintain their usual dietary habit and, if possible, avoid the use of medications throughout the course of the study.

\section{Sample Collection}

A sample of $5 \mathrm{ml}$ of venous blood was collected from each subject and dispensed into lithium heparin bottles before and after 30 days of coffee consumption. Plasma was obtained by centrifugation for $5 \mathrm{~min}$ at 3,000 rpm and separated into plain bottles for analysis. Randox enzymatic kit (Randox Laboratories, United Kingdom) was employed for the in vitro determination of the activity of alanine transaminase (ALT) and aspartate transaminase (AST) in plasma, using the colorimetric method of Reitman and 
Table 1. Mean and standard deviations of plasma concentration of liver enzymes, bilirubin and protein in coffee consumers $(\mathrm{n}=$ 30)

\begin{tabular}{lccc}
\hline Parameters & Baseline & 30-day intake & p value \\
\hline AST, IU/l & $2.0 \pm 1.0$ & $5.0 \pm 0.4$ & $<0.001$ \\
ALT, IU/l & $5.0 \pm 3.6$ & $9.0 \pm 3.4$ & $<0.001$ \\
ALP, IU/l & $93 \pm 13$ & $96.0 \pm 14$ & $<0.01$ \\
TB, mmol/l & $140 \pm 2.5$ & $156 \pm 1.8$ & 0.05 \\
CB, mmol/l & $63 \pm 1.1$ & $68 \pm 1.0$ & $\mathrm{NS}$ \\
TP, g/l & $66.5 \pm 5.6$ & $67.7 \pm 6.1$ & $<0.05$ \\
ALB, g/l & $38.2 \pm 5.1$ & $39.4 \pm 5.2$ & $<0.05$ \\
\hline
\end{tabular}

$\mathrm{TB}=$ Total bilirubin; $\mathrm{CB}=$ conjugated bilirubin; $\mathrm{TP}=$ total protein; $\mathrm{ALB}=$ albumin; $\mathrm{NS}=$ not significant; $\mathrm{SD}=$ standard deviation; $\mathrm{t}=$ Student's $\mathrm{t}$ value.

Table 2. Mean and standard deviations of plasma concentration of liver enzymes, bilirubin and protein in male coffee consumers $(\mathrm{n}=30)$

\begin{tabular}{lccl}
\hline Parameters & Baseline & 30-day intake & p value \\
\hline AST, IU/l & $2.0 \pm 2.0$ & $5.0 \pm 2.0$ & $<0.001$ \\
ALT, IU/l & $5.0 \pm 4.0$ & $10.0 \pm 3.0$ & $<0.001$ \\
ALP, IU/l & $100.0 \pm 10.0$ & $104.0 \pm 12.0$ & $<0.05$ \\
TB, mmol/l & $161 \pm 2.4$ & $169 \pm 1.6$ & NS \\
$\mathrm{CB}, \mathrm{mmol} / \mathrm{l}$ & $70 \pm 1.2$ & $67 \pm 1.2$ & $\mathrm{NS}$ \\
$\mathrm{TP}, \mathrm{g} / \mathrm{l}$ & $68.3 \pm 5.5$ & $69.2 \pm 5.7$ & $\mathrm{NS}$ \\
$\mathrm{ALB}, \mathrm{g} / \mathrm{l}$ & $39.9 \pm 5.5$ & $40.7 \pm 5.1$ & $\mathrm{NS}$ \\
\hline
\end{tabular}

$\mathrm{TB}=$ Total bilirubin $\mathrm{CB}=$ conjugated bilirubin; $\mathrm{TP}=$ total protein; $\mathrm{ALB}=$ albumin; $\mathrm{NS}=$ not significant $\mathrm{t}=$ Student's $\mathrm{t}$ value.

Table 3. Mean and standard deviations of plasma concentration of liver enzymes, bilirubin and protein in female coffee consumers $(\mathrm{n}=30)$

\begin{tabular}{lrcc}
\hline Parameters & Baseline & 30-day intake & p value \\
\hline AST, IU/l & $2.0 \pm 1.0$ & $4.0 \pm 3.0$ & $<0.05$ \\
ALT, IU/l & $4.0 \pm 3.0$ & $9.0 \pm 4.0$ & $<0.001$ \\
ALP, IU/l & $81.0 \pm 4.0$ & $84.0 \pm 7.0$ & NS \\
TB, mmol/l & $108 \pm 1.1$ & $133 \pm 1.5$ & $<0.01$ \\
$\mathrm{CB}, \mathrm{mmol} / 1$ & $56 \pm 0.6$ & $68 \pm 0.9$ & $<0.05$ \\
$\mathrm{TP}, \mathrm{g} / \mathrm{l}$ & $63.8 \pm 4.8$ & $65.4 \pm 6.1$ & $\mathrm{NS}$ \\
$\mathrm{ALB}, \mathrm{g} / \mathrm{l}$ & $36.0 \pm 5.5$ & $37.5 \pm 4.8$ & $\mathrm{NS}$ \\
\hline
\end{tabular}

$\mathrm{TB}=$ Total bilirubin $; \mathrm{CB}=$ conjugated bilirubin; $\mathrm{TP}=$ total protein; $\mathrm{ALB}=$ albumin; $\mathrm{NS}=$ not significant; $\mathrm{t}=$ Student's $\mathrm{t}$ value.
Frankel [20]. Randox enzymatic kit (Randox Laboratories, UK) was also used for the in vitro determination of ALP activity in plasma, according to the colorimetric method of Englehardt et al. [21]. The method of Jendrassik and Grof [22] was employed for the determination of plasma total and conjugated bilirubin concentration, while plasma total protein and albumin concentrations were carried out using the Biuret method and the bromocresol green method of Doumas and Watson [23], respectively. Quality control sera (Randox Laboratories, UK) were used for quality assessment.

\section{Statistical Analysis}

Results were expressed as mean \pm standard deviation. Pairwise comparison of means was made using the nonparametric $t$ test and $\mathrm{p}<0.05$ regarded as significant.

\section{Results}

Compared to baseline values (table 1) in all subjects, coffee consumption for 30 days significantly increased mean plasma AST and ALT ( $p<0.001$ ), respectively. However, ALT increased more than AST did. ALP also significantly increased after 30 days of coffee consumption. Significant increases in the mean concentration of total bilirubin $(\mathrm{p}<0.05)$, total protein $(\mathrm{p}<0.05)$ and albumin $(\mathrm{p}<0.05)$ were also observed after regulated coffee intake. The difference in mean concentration of conjugated bilirubin was not significant $(\mathrm{p}>0.05)$.

In male subjects, the mean plasma activities of AST and ALT were significantly increased $(\mathrm{p}<0.001)$. ALP was also significantly increased compared to baseline values ( $\mathrm{p}<0.05)$, whereas bilirubin (total and conjugated), total protein and albumin were not significantly altered ( $p>0.05$, table 2). Consumption of coffee for 30 days in female subjects (table 3 ) significantly raised the mean plasma activity of AST $(\mathrm{p}<0.05)$ and ALT $(\mathrm{p}<$ 0.001). As in male subjects, ALT in female subjects increased more than AST did. The mean concentration of total bilirubin $(\mathrm{p}<0.01)$ and conjugated bilirubin $(\mathrm{p}<$ 0.05 ) was significantly increased after 30 days of coffee consumption, whereas ALP, total protein and albumin were not significantly altered $(\mathrm{p}>0.05)$.

\section{Discussion}

It has been hypothesized that liver enzymes are a target for caffeine or other components of coffee [15]. In this study, coffee consumption for 30 days resulted in a significant increase in mean plasma activity of ALT and AST over baseline values. It was observed that AST was 
less affected by coffee consumption than ALT levels. This study confirmed the findings of other investigators [17, 24-27] who observed that subjects consuming coffee diterpenes had a significant rise in mean concentrations of serum liver aminotransferases, and also that ALT rose more than AST did [17]. Urgert et al. [26] had two groups of subjects: one group took unfiltered coffee providing 39 $\mathrm{mg}$ cafestol and $49 \mathrm{mg}$ kahweol, while the other group took boiled coffee containing $11 \mathrm{mg}$ cafestol and $13 \mathrm{mg}$ kahweol. Both the unfiltered and boiled coffee caused significant increases in plasma ALT and AST. It is possible that the outer membrane of hepatocytes has become leaky but that cells are still largely intact. ALT is predominantly present in the cytoplasm of hepatocytes, whereas AST is predominantly present in the mitochondria. However, when hepatocytes sustain more severe injury, the serum levels of AST will exceed that of ALT [28]. These elevations of liver aminotransferase activity in serum may be indicative of disturbed integrity of liver cells. However, it has been reported that serum activities of transaminases returned to baseline after withdrawal of coffee [26]. In contrast, Casiglia et al. [15] observed that subjects who consumed 3 or more cups of coffee per day had significantly lower plasma levels of liver enzymes when compared to those consuming $0-2$ cups per day. Differences observed in the plasma activities of liver enzymes in the present study did also not agree with the findings of Bravi et al. [29] and other investigators, who reported an inverse relationship between coffee consumption and liver enzymes.

Significant increases in the mean concentration of ALP, total bilirubin, and total protein were observed in this study. This is contrary to the findings of Boekschoten et al. [18], who observed a tendency for ALP to be de- creased. The latter study also observed a 38\% increase in bilirubin levels during the follow-up measurement compared to baseline, 4 weeks after termination. The increase in ALP and total bilirubin observed in the present study, though significant, was too small to be suggestive of cholestatic disease. ALP is strongly increased in cholestatic disease [30], which is not the case following 30 days of coffee consumption. The increase in total protein may suggest that coffee consumption has a considerable effect on the synthetic function of the liver.

Factors that could unduly influence the outcome of this study were minimized as detailed below. All the volunteers were screened to ensure they were apparently healthy, neither smoked nor consumed alcohol and were not on medication. All these have been observed to cause slight or moderate elevations of both AST and ALT activities amongst others [28]. The diet consumed by the subjects was also assumed not to vary significantly since they were advised on the importance of maintaining their usual diet.

\section{Conclusion}

This study showed an increase in AST, ALT, ALP, total bilirubin, and plasma protein. This suggests that shortterm consumption of coffee could have a significant effect on the integrity of the liver functions studied. It is possible that liver enzymes could be a target for caffeine or other components of coffee; however, the mechanism of the effect presently remains unclear. Further studies regarding the mechanism through which coffee affects the liver is highly needed.

\section{References}

1 Choi HK, Curhan G: Coffee, tea and caffeine consumption and serum uric acid level: the third national health nutrition examination survey. Arthritis Rheum 2007;57:816-821.

2 Smith RF: History of coffee; in Clifford MN, Wilson KC (eds): Coffee: Botany, Biochemistry and Production of Beans and Beverage. Westport, AVI Publishing Co, 1985, pp 1-12.

3 Charrier A, Berthaud J: Botanical classification of coffee; in Clifford MN, Wilson KC (eds): Coffee: Botany, Biochemistry and Production of Beans and Beverage. Westport, AVI Publishing Co, 1985, pp 13-47.

Coffee Consumption Could Affect Some Biochemical Parameters
4 Zampelas A, Panagiotakos DB, Pitsavos C, Chrysohoou C, Stefanadis C: Associations between coffee consumption and inflammatory markers in healthy persons: the ATTICA study. Am J Clin Nutr 2004;80:862-867.

5 Klatsky AL, Morton C, Udaltsova N, Friedman D: Coffee, cirrhosis, and transaminase enzymes. Arch Intern Med 2006;166:11901195.

6 Fukushima Y, Ohie T, Yonekawa Y, Yonemoto K, Aizawa H, Mori Y, Watanabe M, Takeuchi M, Hasegawa M, Taguchi C, Kondo K: Coffee and green tea as a large source of antioxidant polyphenols in the Japanese population. J Agric Food Chem 2009;57:12531259.
7 Johnson S: The multifaceted and widespread pathology of magnesium deficiency. Med Hypotheses 2001;56:163-170.

8 Sherwin JE: Liver function; in Kaplan LA, Pesce AJ (eds): Clinical Chemistry. Theory, Analysis and Correlation. St Louis, Mosby 1989, pp 359-372.

$\checkmark 9$ Nehlig A, Daval JL, Debry G: Caffeine and the central nervous system: mechanisms of action, biochemical, metabolic and psychostimulant effects. Brain Res Brain Res Rev 1992;17:139-170.

10 Arnaud MJ: The pharmacology of caffeine. Prog Drug Res 1987;31:273-313. 
-11 Ortweiler W, Simon HU, Splinter FK, Peiker G, Siegert C, Traeger A: Determination of caffeine and metamizole elimination in pregnancy and after delivery as an in vivo method for characterization of various cytochrome p-450 dependent biotransformation reactions (in German). Biomed Biochim Acta 1985;44:1189-1199.

12 Bolton S, Null G: Caffeine: psychological effects, use and abuse. Orthomolecular Psychiatry 1981;10:202-211.

-13 Pereira M, Parker AD, Folsom AR: Coffee consumption and risk of type-2 diabetes mellitus: an 11-year prospective study of 28 , 612 post-menopausal women. Arch Intern Med 2006;166:1311-1316.

14 Cadden IS, Partovi N, Yoshida EM: Possible beneficial effect of coffee on liver disease and function. Aliment Pharmacol Ther 2007;27: 90-91.

15 Casiglia E, Spolaore P, Ginocchio G, Ambrosio GB: Unexpected effects of coffee consumption on liver enzymes. Eur J Epidemiol 1993;9:293-297.

16 Akashi I, Kagama K, Hirand T, Oka K: Protective effects of coffee-derived compounds on lipopolysaccharide/D-galactosamine induced liver injury in rats. J Pharm Pharmacol 2009;61:473-478.
17 Urgert R, Essed N, Van der Weg G, Kosimeijer-Schuil TG, Katan MB: Separate effects of the coffee diterpenes cafestol and kahweol on serum lipids and liver aminotransferases. Am J Clin Nutr 1997;65:519-524.

18 Boekschoten MV, Schouten EG, Katan MB: Coffee bean extracts rich and poor in Kahweol both give rise to elevation of liver enzymes in healthy volunteers. Nutr J 2004;3:7.

19 Onuegbu, AJ, Agbedana EO: The effects of coffee consumption on serum lipids and lipoprotein in healthy individuals. Afr J Med Med Sci 2001;30:43-45.

20 Reitman S, Frankel S: A colorimetric method for the determination of serum glutamic oxalocetic acid and glutamic pyruvic transaminases. Am J Clin Pathol 1957;28:56-63.

21 Englehardt A, et al: Measurement of alkaline phosphatase. Aerztl Labor 1970;16:42.

-22 Jendrassik L, Grof P: Vereinfachte photometrische Methoden zur Bestimmung des Blutbilirubin. Biochem Z 1938;297:81-89.

23 Doumas B, Watson W: The determination of serum albumin using bromocresol green. Clin Chim Acta 1971;31:87.

24 Honjo S, Kono S, Coleman MP, Shinchi K, Sakurai Y, Todoroki I, Umeda T, Wakabayashi K, Imanishi K, Nishikawa H, Ogawa S, Katsurada M, Nakagawa K, Yoshizawa N: Coffee consumption and serum aminotransferases in middle-aged Japanese men. J Clin Epidemiol 2001;54:823-829.
25 Weusten-van der Wouw MPME, Katan MB, Viani R: Identity of the cholesterol-raising factor from boiled coffee and its effect on liver function enzymes. J Lipid Res 1994;35: 721-733.

26 Urgert R, Schulz AG, Katan MB: Effects of cafestol and kahweol from coffee grounds on serum lipids and serum liver enzymes in humans. Am J Clin Nutr 1995;61:149-154.

27 Van Rooij J, van der Stegen GHD, Schoemaker RC: A placebo-controlled parallel study of the effect of two types of coffee oil on serum lipids and transaminases: identification of chemical substances involved in the cholesterol-raising effect of coffee. Am J Clin Nutr 1995;61:1277-1283.

28 Burtis CA, Ashwood ER: Liver function; in Burtis CA, Ashwood ER (eds): Tietz Fundamentals of Clinical Chemistry, ed 5. Philadelphia, Saunders, 2001, pp 747-770.

29 Bravi F, Bosetti C, Tavani A, Bagnardi V, Gallus S, Negri E, Franceschi S, La Vecchia C: Coffee drinking and hepatocellular carcinoma risk: a meta-analysis. Hepatology 2007;46:430-435.

30 Mayne PD: The liver and gall stones; in Clinical Chemistry in Diagnosis and Treatment, ed 6. London, ELBS/Arnold, 2005, pp 279298 